\title{
APPROACHING THE BENCH: TEACHING MAGISTRATES AND JUDGES HOW TO WORK EFFECTIVELY WITH INTERPRETERS
}

\author{
Sandra Hale \\ s.hale@unsw.edu.au \\ University of New South Wales
}

\begin{abstract}
Reports about judicial misunderstandings of the interpreting process are common (Berk-Seligson 2008; Morris 2010; Hale 2011a). The misconception that interpreters 'just translate' from one language to another by swapping individual words from language A to language B in a mechanical, uncomplicated way, is still prevalent among some legal professionals. Research into court interpreting, however, has highlighted the complexities involved in attempting to achieve a pragmatically accurate rendition in conditions that are usually less than adequate (Hale 2004; Mikkelson 2008; Hale \& Stern 2011). In order for court interpreting to be successful, all parties must be aware of its challenges and share the responsibility for effective communication (Ozolins $\&$ Hale 2009). This chapter will describe the contents and structure of a workshop designed and delivered by the author to Australian magistrates, judges and tribunal members on how to work effectively with interpreters, for over ten years. It will further discuss the positive concrete outcomes achieved through the raising of awareness among the judiciary about the importance of interpreters in the legal system.
\end{abstract}

\section{Resumen}

Varios autores han escrito sobre la falta de entendimiento del personal judicial en cuanto al proceso de la interpretación en diferentes países del mundo (Berk-Seligson 2008; Morris 2010; Hale 2011a). El concepto erróneo de que los intérpretes 'sólo traducen' de un idioma a otro mediante el canje de palabras individuales de la lengua A a la lengua B de una manera mecánica y sin complicaciones aún prevalece entre algunos. La investigación sobre la interpretación judicial, sin embargo, ha puesto de 
relieve las complejidades que se manifiestan al tratar de lograr que una interpretación sea pragmáticamente fiel al original, en condiciones laborales que, por lo general, dejan mucho que desear (Hale 2004; Mikkelson 2008; Hale \& Stern 2011). A fin de lograr una comunicación eficaz por medio del intérprete, todas las partes deben ser conscientes de los retos que esto supone y han de aceptar la asunción de parte de la responsabilidad que dicha interacción implica (Ozolins \& Hale 2009). Este capítulo describirá el contenido y la estructura de un taller diseñado e impartido por la autora durante más de diez años a jueces, magistrados y demás personal judicial de Australia sobre cómo trabajar con intérpretes de un modo eficaz. Se discutirán, además, los resultados positivos logrados a través de la toma de conciencia en el poder judicial de la importancia de los intérpretes en el sistema jurídico.

Keywords: Working with interpreters. Judges. Magistrates. Tribunal members. Raising awareness of interpreting issues.

Palabras clave: Trabajo con intérpretes. Jueces. Magistrados. Miembros del tribunal. Toma de conciencia del papel de la interpretación.

Manuscript received on May 28, 2014

and accepted for publication on September 15, 2014. 


\section{Introduction}

Reports about judicial misunderstandings of the interpreting process are common (Morris 2010; Berk-Seligson 2008; Hale 2011a). The misconception that interpreters 'just translate' from one language to another by swapping individual words from language A to language B in a mechanical, uncomplicated way, is still prevalent among some legal practitioners. A recent Australian survey (Hale 2011b) of 148 magistrates, judges and tribunal members on issues surrounding legal interpreting found mixed levels of understanding about the interpreting process and the interpreter's role. While some were supportive of interpreters and demonstrated a good understanding of their role, others were adamant that all interpreters do is "...simply translate what is said literally..." (quote 34 in Hale 2011b: 42). This simplification of the interpreter's task has implications for the status of the profession, the levels of training and types of qualifications required, the working conditions provided and the remuneration attached to their work. If the work of interpreters is seen as a 'simple task' by those who use their services, stringent training and certification requirements will not be considered necessary, which will in turn justify levels of remuneration that are adequate only for unskilled occupations. Similarly, interpreters will not be treated as equal professionals nor provided with adequate working conditions to help them perform to the best of their "skill and ability", which is what they are required to swear under oath or affirm to do at the start of every case in Australia. Indeed one of the prevalent areas of disagreement between the judiciary and interpreters is the need for any briefing or preparation materials (Hale 2013). Interpreters want as much information as possible in order to be well prepared to do their job, while many of the judiciary argue that there is "... generally no need. They just have to interpret for the person" (quote 24, in Hale 2011b: 30).

Research into court interpreting has highlighted the complexities involved in attempting to achieve a rendition that is pragmatically accurate from the source to the target language in conditions that are, for the most part, less than adequate (Hale 2004; Mikkelson 2008; Hale \& Stern 2011). In addition to the inherent complexities of interpreting in general, court settings present 
special linguistic challenges for interpreters. The archaic use of language, the ritualistic discourse practices, the strategic use of questions and the significance of the discourse practices of the witnesses in establishing their credibility, all impinge on the interpreter's ability to produce an adequate target language version of the original. In order for court interpreting to be successful, all parties must be aware of these special characteristics and they all must share some of the responsibility for successful communication (Ozolins $\&$ Hale 2009). Interpreters must be educated on the discourse of the courtroom and on the requirements of the setting, and lawyers and the judiciary must be educated on the intricacies of interpreting and on what interpreters need in order to fulfill their court appointed role. This paper will describe the contents and structure of a presentation the author has designed and delivered to Australian magistrates, judges and tribunal members on how to work effectively with interpreters, for over ten years. The paper will also discuss the positive concrete outcomes achieved through the raising of awareness among the judiciary about the importance of interpreters in the legal system.

\section{Approaching the Bench}

The misconception held by legal professionals about the interpreting process is understandable given they are not linguists or language professionals. Depending on the geographical area or the particular jurisdiction, legal professionals will have varying degrees of contact with interpreters in their everyday work. To some, interpreted cases may be a very rare occurrence; to others they may be more frequent. For this reason, many will see interpreting issues as peripheral to their work, and will not go out of their way to learn more about it. While interpreters, especially trained ones, see the value of acquiring knowledge about the goals and requirements of those other professionals with whom they work because they understand that adequate background knowledge will help improve their interpreting performance, other professionals who at times need to use interpreting services, may not be aware that their own ability to perform their duties will be affected by the quality of the interpretation. Quality of interpretation depends on a number of factors, which include the performance of all participants. Interpreting scholars and practitioners therefore need to reach out to other professions to raise awareness about the importance of mutual understanding about each other's needs, but also about the nature of interpreting and how all speakers and participants in an interpreted event can significantly affect the quality of the interpretation. Legal professionals cannot be expected to attend interpreters' conferences or to read their journals, albeit some do. Therefore, interpreting scholars need to 
write articles for legal professionals and publish in the journals, newsletters or magazines they are likely to read. In this descriptive paper $\mathrm{I}^{1}$ will share my experience in teaching magistrates, judges and tribunal members on how to work with interpreters. Due to the descriptive nature of the paper, I have decided to write it in the first person. The same presentation can be adapted for lawyers. The aim of this paper is to provide a framework that others can use to present similar workshops to legal practitioners in their own countries or regions. Indeed, the same presentation has already been adapted and presented to medical students (see Friedman-Rhodes \& Hale 2010), as part of a small-scale study which indicated concrete positive outcomes.

My first approach was the publication of the article "The complexities of the bilingual courtroom" (Hale 2001) in The Law Society Journal, which is the journal of the lawyers' professional association. Very soon after the article was published I received a telephone call from the Law Society asking me to do a presentation for their members. As a result of that presentation, I was subsequently recommended to other organisations to give the same presentation to different legal audiences. This led to regular annual workshops for different organisations, including the Bar Association, the National Judicial College of Australia, the Australasian Institute of Judicial Administration, the different state Judicial Commissions, and the different tribunals (e.g. Refugee and Migration Review Tribunal, Compensation Commission of NSW). The audiences range from twenty to fifty participants. In addition to these, I have also approached the law schools of the two universities in which I have worked and have given similar presentations to Law students. However, the majority of the workshops since 2001 have been addressed to new magistrates and judges. The awareness raised by the workshops has also contributed to interpreter issues being included in subsequent legal practitioners' conferences, which usually dedicate at least one session to cross linguistic and cross cultural communication issues.

\section{Workshop structure}

Legal audiences are often skeptical about the usefulness of a session on interpreting issues. This was made manifest in a number of comments in the workshop evaluations such as:

1. The author has over twenty years' experience as an interpreter and educator of interpreters. She has conducted research into interpreting quality and interpreting pedagogy. There are no published resources in Australia for teaching legal professionals on how to work with interpreters. 
"I learnt a great deal I didn't know that I didn't know until this session"

"A real eye-opener"

"I was happily surprised"

It is crucial that the workshop be pitched at the correct level to maintain the interest of a very demanding audience. A number of the participants expressed to me that previous presentations on interpreter issues delivered by other people had been very basic, dealing only with the mechanical protocols of how to work with an interpreter, and that they had not gained much from them. Teaching very basic content to a very sophisticated audience will only reinforce the misconception that interpreting is a simple task, which only requires simple instructions.

My workshop has a ninety-minute duration and it is divided into five sections. The first section aims to establish the audience's expectations of interpreters and to elicit their experiences with interpreters in the past. In the second section I present an excerpt from a hearing where a magistrate instructs an interpreter, and I ask the audience to give their evaluation of the magistrate's instructions. The third section discusses the language hierarchy (from the word to the discourse) (see Hale 2007) and highlights linguistic and cultural differences across languages. The fourth section discusses the meaning of accuracy of interpreting in legal settings and the fifth section explains the interpreting process and highlights the complexities of interpreting accurately in light of what they heard in the previous four sections, and provides practical guidance on how to work effectively with interpreters. Depending on the dynamics of the group, I sometimes add a role-play and a video presentation. I will explain each of these sections in detail below.

\subsection{Workshop section 1: Introduction}

The introduction to the workshop is crucial. It is important to engage the audience from the very beginning. For this reason, I start by asking them two questions: 1 . What do you expect of interpreters? and 2. How have those expectations been met in your experience? The answers I usually receive to the first question are: to translate everything literally, to translate everything word for word, to be accurate, to just translate and not add or give opinions or coach the witness, to be ethical and professional. There are at times participants in the audience who have read about interpreting issues, have attended previous workshops or are bilingual themselves, who will give more nuanced answers, or who will speak of cross cultural issues and the need to go beyond the literal. However, for the most part, I elicit the expected response, which feeds into the rest of my presentation. In response to question 2, the 
participants say that they have experienced a wide range of different levels of professionalism and competence in interpreters with whom they have worked. After acknowledging their answers and writing the main ones on the board, I tell them that we will discuss these expectations and why they are sometimes met and sometimes not met, throughout the workshop. I then present them with the following statement and ask them to tell me what they think it means:

(1) "By God went-I to house brother-me and hit-I sister-me telephone"2 (Hale 2007)

The types of answers I receive include different variations of the concept: "My God! I went to my brother's house and hit my sister with the telephone". After receiving a few suggestions, I tell them to remember the phrase because we will come back to it later to discuss it after I have given them further information. This intrigues them and maintains their interest.

\subsection{Workshop section 2: Evaluation of a quote from a magistrate}

At this point I put up on the screen the excerpt that appears below, which is a quote from a magistrate presiding over a Local Court hearing:

(2) "Just translate what I'm saying to the defendant. You can sit down for a moment, just tell him what I'm saying. I'm now giving reasons for the decision I'm about to come to. The defendant was initially charged with knowingly contravening a prohibition or a restriction specified in an Apprehended Domestic Violence Order... Did he understand all that"

After reading the statement aloud, I open the floor for comments from the audience, leading the discussion to cover the points below. Most participants state that they would not instruct the interpreter in this way for the following reasons: it is unclear when the magistrate stops addressing the interpreter and starts addressing the defendant, it is too long and it is too technical. I then highlight the first directive "Just translate" and ask them to tell me what this implies. Some comment that it means, "translate and do nothing else", but some identify the connotation of the word "just" as implying that it is a simple task. Some object to the magistrate telling the interpreter what to do, when the interpreter should already know what their role is. I then explain the difference between translating and interpreting. This distinction comes to many of them as a surprise, as they are accustomed to using the term "interpret"

2. I acknowledge Stuart Campbell for providing the literal translation of the original phrase in Arabic. 
as something that only lawyers can do. When it is explained to them that it is the technical term for oral translation, they feel much more comfortable with the term. The phrase "just tell him what I'm saying" elicits the same responses as the first phrase. We then discuss the basic interpreting protocol of using the direct approach by speaking in the first and second grammatical persons rather than in indirect speech using the third person. The final discussion on this excerpt surrounds the question to the interpreter about whether the defendant understood everything, highlighting that it is impossible for the interpreter to know whether someone else understood something or not. This in turn leads to a discussion of how to ensure intelligibility and what strategies to use, such as asking the question directly to the defendant, asking checking question or requesting the defendant to tell the court what s/ he understood in their own words.

\subsection{Workshop section 3: The hierarchy of language}

Following what is generally a very lively discussion, I move on to linguistic theory, after which I reveal the meaning of the odd statement I showed them in the introduction (see example 1 above). At this point I present them with a slide entitled "The hierarchy of language" which contains the upside down pyramid shown in Figure 1:

Figure 1: The hierarchy of language (Hale 2007)

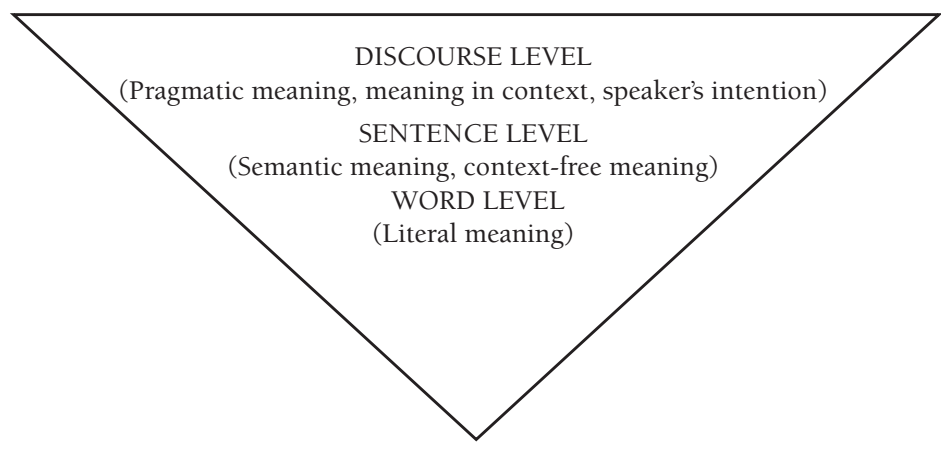

I explain that language can be divided into three main components - the word, the sentence and the discourse - where words are put together to form sentences and sentences are put together to form larger chunks of discourse. I then ask if anyone has studied a second language, and whether they have ever had the experience where they understood every word but they still did not understand what the person meant by it (Cook 1989). This leads to a 
discussion about producing meaning in context, taking into account the interlocutors' background or shared knowledge, relationship to each other and cultural conventions. This is followed by a discussion of pragmatic speech act theory (Austin 1962), the cooperative principle (Grice 1975) and cross-cultural pragmatics (Wierzbicka 2003/2009), complemented by many examples. I then present the following statement and ask them to tell me what it means:

(3) "You son of a bitch!"3

Firstly I ask them to tell me what it means literally, at the word level, to which I receive answers such as: "you are a male offspring of a female dog". I then ask them to tell me what they would understand by it, beyond its literal meaning and the answer I receive is "an insult". I then put the utterance in the context of two old friends who have not seen each other for a while and when they meet, one says this to the other. When asked about its meaning in this context, they all agree that it could in fact be a term of endearment. In other words, the context can change the meaning to mean the opposite of what they had expressed earlier. We continue in this manner, discussing a number of different examples to illustrate the complexity of language, even when we are dealing with one language in monolingual contexts.

I then explain that different languages differ at all the levels of the language hierarchy and present examples of lexical gaps, grammatical differences across languages, gaps in semantic fields and different ways of producing speech acts across languages. I also discuss cross-cultural differences, which can lead to different understandings of utterances. One example presented here to generate discussion is one I provide in a previous publication (Hale 2007), where a witness states that his wife and he were undecided whether they should spend a considerable amount of money they won on the lottery on paying off their mortgage or on their daughter's fifteenth birthday celebration. I ask if they consider such a proposition off in any way, to which most reply in the positive. I then explain the cultural implications of a daughter's fifteenth birthday in some Latin American countries, which makes the utterance culturally appropriate. Other examples of cross cultural differences are presented (see Hale 2014) and we discuss how all of these complexities present real challenges for interpreters, using examples from research data (see Berk-Seligson 1990 and Hale 2004 for examples from authentic data).

3. Note that this is not a very offensive remark in Australia. 


\subsection{Workshop section 4: The meaning of accuracy}

I start this section with the odd phrase in the introduction and with its accurate pragmatic translation:

(4) "By God went-I to house brother-me and hit-I sister-me telephone"

(Literal translation from Arabic)

"I'm telling you, I went to my brother's place and phoned my sister"

I ask them to now surmise why the first version is different from the second and why they were able to understand every word in the first version but misunderstood the meaning completely. Generally they can now clearly see that the original was a literal translation and the last one is a pragmatic translation. I ask them which one they would expect a good interpreter to produce, and invariably they all say the second one. However, they question why the words 'God' and 'hit' do not appear in the second translation. This leads to a discussion of the differences between English and Arabic at all the levels of the language hierarchy. I highlight the morpho-syntactic differences, the lexical differences, which include the collocation of the verb 'hit' with 'telephone' similar to the English 'made' with 'a call' or 'dialed' with 'a number', all of which carry metaphorical meanings. The discussion surrounding the use of the term 'God' leads to cross cultural pragmatic differences and what is considered to be appropriate or inappropriate in different speech events.

This discussion is followed by what constitutes accuracy of interpreting in a legal setting. By this stage they are convinced that it does not mean a literal, word-for-word translation as some of them had stated at the beginning of the workshop. I then present them with the theory I use to train interpreters about how to aim for accuracy. This is based on dividing each utterance into a locutionary, an illocutionary and a perlocutionary act (see Hale 2007 for a full discussion on the application of this theory to interpreting accuracy). The locutionary act equates to the literal level, as it refers to the words that form the utterance. The most important of the three is the illocutionary act, which indicates what the speaker wants to convey with those words. The perlocutionary act is also crucial for interpreters, as it refers to how listeners would react to the utterance. Although speakers cannot control the perlocutionary act, they can aim at producing certain reactions in their listeners. Interpreters, therefore, would undergo a mental analysis of what they hear. The more the interpreter knows about the speaker and his/her culture, professional needs,

4. I acknowledge Stuart Campbell for providing the pragmatic translation of the original phrase in Arabic. 
goals of the interaction and subject matter, the better equipped s/he will be to understand the illocutionary point and force of the utterance. In deciding on the best way to render such illocutionary act, the interpreter will also consider his/her own reaction to the utterance, which constitutes the perlocutionary act. For example, the mental question an interpreter would normally ask him/ herself is "How would this be expressed in the target language to achieve the reaction it achieved in the source language?" The resultant interpreted utterance may be very distant in words and structure from the original, but still be the most accurate rendition. This discussion is the most complex and controversial. Many examples from authentic interpreted data are shown to illustrate the different points (see Hale 2004 for examples). At this stage I also address the fact that interpreting is not an exact science, that interpreters are subjective human beings and that different interpreters will produce different renditions. I invoke the linguistic actor metaphor, where interpreters, not unlike actors, act out the parts of the different interlocutors, attempting to be as faithful as possible to the 'author' or the 'script' but still maintaining their individual style.

\subsection{Workshop section 5: Practical guidance on working with interpreters effectively}

The aim of this section is to raise the awareness that interpreters do not work in isolation and that they cannot be held fully responsible for the quality of the interpretation. The different factors that can affect interpreting quality are then outlined. These include 'discourse-internal' factors and 'discourse-external' factors (Hale 2007). Discourse internal factors relate to all the issues I have already outlined above and for the most part fall within the interpreter's competence or responsibility, except for the discourse behaviours of the other interlocutors. Here I highlight the other speakers' responsibility towards ensuring accurate interpreting by speaking clearly and coherently and avoiding overlapping speech. I then present to them a number of examples of poorly expressed utterances from research data that interpreters are typically confronted with. One such example appears below.

(5) "So why if you have been threatened by as you say said terrorists because of your brother's election in the council and your car has been broken, why

didn't you have any fear of persecution before you travelled to Australia?"

(Szldy \& Ors vs Minister for Immigration \& Anor [2008] FMCA 1684:16)

I show them the above question on the screen, give them time to read it and take it off the screen. I then ask them to repeat the same question back to me 
verbatim in English. To this date no one has been able to repeat the question accurately.

Another exercise I conduct involves inviting three volunteers to come to the front. I provide them with a script in English based on a court transcript which two of the volunteers read out to each other, acting out the roles of questioner and answerer. The third volunteer 'simply' needs to listen and repeat everything verbatim in English. As they are attempting this exercise, the rest of the audience follows the script to assess accuracy. As in the previous exercise, as soon as the utterances become long or complex, the volunteer acting as monolingual interpreter can no longer follow. These exercises highlight the unrealistic expectations placed on interpreters, especially by those who believe that all interpreters need to do is "just translate" everything word for word. Ways they can help avoid these types of questions from lawyers in their court are then proposed.

Discourse external factors include the availability of briefing and background materials, physical working conditions, and remuneration. This section emphasizes the fact that the very best interpreter cannot be expected to perform adequately under poor working conditions and that the best interpreters usually do not last in the profession due to the low levels of remuneration. Results of research into current working conditions are then presented and discussed, with a discussion on how judicial officers can help improve the situation (see Hale 2011b).

The next section deals with practical issues surrounding interpreter education and training, availability, accreditation/certification and recruitment, as well as with basic guidelines on how to work with interpreters. At this stage I alert them to the one-page set of guidelines I prepared which has been incorporated in a number of Bench books around Australia (see Appendix 1).

\section{Workshop evaluations}

The organizers of the programs routinely ask the participants to assess each of the sessions by providing open comments and some by asking for a rating. A letter with a sample list of open comments, and some with a numerical result (ratings of $97.06 \%$ and $98.91 \%)^{5}$ is then sent to the presenters. The presenters have no input into these evaluations. The evaluations for my session are consistently very positive. Some of the open comments worth noting include:

5. Ratings for the workshops delivered as part of the annual judicial orientation for the Judicial College of Victoria (in 2013 and 2014) 
"Very relevant to know how the interpreters feel about their treatment by magistrates"

"Enlightening"

"Very important issues... will definitely take these issues away with me long term"

"Very worthwhile - topic needs to be heavily exposed"

"I found this a fascinating and useful discussion"

"The BEST session on interpreting I have seen"

"Great session. New-found respect for interpreters. Without it, I suppose I would have been very thoughtless in this area"

"I will be much kinder to interpreters"

"I learnt a great deal I didn't know that I didn't know until this session"

"Terrific insight into problems for interpreters - did not suspect the difficulties they faced"

"Best "non-legal' session"

"Much more interesting and useful than I had expected"

"Excellent, thought provoking, extremely useful"

"I have worked with interpreters many times and almost all of this was news to me! I wish I had known all this years ago". ${ }^{6}$

The only negative comment ever received was that the session was not long enough, as there was too much to cover and discuss. This in itself further highlights the interest generated by the presentation.

The evaluations reveal a number of important issues: 1) that misconceptions held by judicial officers can be easily dispelled when a convincing argument is presented to them; 2) that judicial officers are genuinely concerned with achieving communication in their courtroom and are willing to help interpreters perform to their best of their skill and ability; 3) that they can become allies and can help educate their colleagues; and 4) that raising their awareness of the difficulties and complexities involved in interpreting leads to an appreciation of and respect for interpreters.

\section{Conclusion}

Teaching the judiciary about how to work with interpreters has been not only very rewarding but also very productive. As a result of the higher level of awareness achieved through these workshops, the different organisations that represent magistrates, judges and tribunal members have included sessions on interpreters in their respective annual conferences. Such fora have

6. Comments from evaluations for workshops delivered to the National Judicial College of Australia, Judicial College of Victoria, NSW Judicial College, and the Annual South Australian Magistrates Conference. 
contributed to a greater dialogue between judicial officers, practising interpreters and interpreter educators and researchers. Another important outcome has been the participation of bodies such as the Australasian Institute of Judicial Administration (AIJA) and the different state departments of Justice as industry partners in research projects about interpreting, with both in-kind and monetary contributions. ${ }^{7}$ Interpreters have also commented on the difference these workshops have made on the way some judicial officers who have received the training treat them (see Hale and Napier, forthcoming). Such an overwhelming positive response points to the fact that it is possible to break down barriers and to work together with the legal profession in order to achieve better outcomes. Nevertheless, it takes much more than raising awareness among the legal profession to ensure quality of interpreting services. The quality of practising interpreters must be the first priority, which can only be achieved through adequate pre-service education and training and needs to be compensated through appropriate levels of remuneration. Only then will interpreters be able to interpret the evidence truly and faithfully.

\section{References}

AUSTIN, John. (1962) How to do things with words. Oxford: Oxford University Press.

Berk-Seligson, Susan. (2008) "Judicial systems in contact. Access to justice and the right to interpreting/translating services among the Quichua of Ecuador." Interpreting 10:1, pp. 9-33.

Berk-Seligson, Susan. (1990) The Bilingual Courtroom. Court interpreters in the judicial process. Chicago: The University of Chicago Press.

FrIEDMAN-RHODES, Elizabeth \& Sandra Hale. (2010) "Teaching Medical Students to work with Interpreters." The Journal of Specialised Translation 14, pp. 121-144.

Cook, Guy. (1989) Discourse. Oxford: Oxford University Press.

GRICE, Paul. (1975) "Logic and Conversation." In: Cole, Peter \& Jerry L. Morgan (eds.) 1975. Syntax and semantics. New York: Academic Press, vol. 3, pp. 41-58.

HALE, Sandra. (2014) "Interpreting culture. Dealing with cross-cultural issues in court interpreting." Perspectives 22:3, pp. 321-331.

7. For example, the project reported in Hale (2011b) was funded by the Australasian Institute of Judicial Administration. The author is also currently undertaking two other major research projects into court interpreting which have the participation of the NSW, Victorian and Queensland departments of Justice. 
HALE, Sandra. (2013) "Helping interpreters to truly and faithfully interpret the evidence: The importance of briefing and preparation materials." Australian Bar Review 37:3, pp. 307-320.

HALE, Sandra. (2011a) "The need to raise the bar: court interpreters as specialised experts." The Judicial Review 10:2, pp. 237-258.

HALE, Sandra. (2011b) Interpreter policies, practices and protocols in Australian Courts and Tribunals. A national survey. Melbourne: Australian Institute of Judicial Administration.

HALE, Sandra. (2007) "The challenges of court interpreting: intricacies, responsibilities and ramifications." Alternative Law Journal, 32:4, pp. 198-202.

Hale, Sandra. (2004) The discourse of court interpreting. Discourse practices of the law, the witness and the interpreter. Amsterdam \& Philadelphia: John Benjamins.

HALE, Sandra. (2001) "The complexities of the bilingual courtroom." Law Society Journal (July 2001), pp. 68-72.

HALE, Sandra \& Ludimila Stern. (2011) "Interpreter quality and working conditions: comparing Australian and international courts of justice." Judicial Officers' Bulletin 23:9, pp. 75-81.

HALE, Sandra \& Jemina Napier (forthcoming). "We're just kind of there': Working conditions and perceptions of appreciation and status in court interpreting" (Submitted, awaiting response).

MiKKELSON, Holly. (2008) "Evolving views of the court interpreter's role. Between Scylla and Charybdis." In: Valero Garcés, Carmen \& Anne Martin (eds.) 2008. Crossing borders in community interpreting. Definitions and dilemmas. Amsterdam \& Philadelphia: John Benjamins, pp. 81-97.

MORRIS, Ruth. (2010) "Court Interpreting 2009: an undervalued and misunderstood profession? Or: will justice speak?" MonTI. Monografías de Traducción e Interpretación 2, pp. 47-79. Electronic version: http://rua.ua.es/dspace/ bitstream/10045/16435/1/MonTI_2_04.pdf

SZLDY \& ORS vs Minister for Immigration \& Anor [2008] FMCA 1684:16.

WierzbickA, Anna. (2003/2009) Cross-Cultural Pragmatics. The Semantics of Human Interaction. Berlin \& New York: De Gruyter Mouton. 


\title{
Appendix I
}

\author{
GUIDELINES FOR MAGISTRATES AND JUDGES ON \\ WORKING WITH INTERPRETERS IN COURT \\ Professor Sandra Hale \\ Interpreting \& Translation, UNSW
}

- Ask interpreters to introduce themselves and state their level of NAATI accreditation and their formal qualifications (e.g. Degree or TAFE qualification in Interpreting)

- Ask them if they have worked in court before. If not, explain their role: "To interpret everything faithfully and impartially in the first/ second grammatical person"

- Remember that interpreting faithfully does not mean interpreting 'literally' - word-for-word translations normally produce nonsensical renditions

- Ask them what resources they will be accessing in court (e.g. on-line glossaries and dictionaries can now be accessed on smart phones and tablets. Interpreters may need to consult them at different stages of the hearing or trial)

- Tell the interpreter to feel free to seek clarification when needed, seek leave to consult a dictionary or to ask for repetitions. (NB: It is a sign of a good interpreter to take such actions when needed, to ensure accuracy of interpretation)

- Explain the interpreter's role to the witness/defendant/accused/jury

- Ask the interpreter when s/he would like to take their breaks - ideally breaks should be provided at least every 45 minutes (Interpreting requires a very high cognitive load and is mentally very taxing)

- Ensure that the interpreter is comfortable and is provided with a chair, a jug of water $\&$ glass, a table to lean on to take notes and a place to put their belongings (such as a bag and umbrella)

- Instruct lawyers and witnesses to speak clearly and at a reasonable pace, and to pause after each complete concept to allow the interpreter to interpret (NB. If you cannot remember the question in full or understand its full meaning, it is very likely the interpreter will not either)

- If there is anything to be read out, provide the interpreter with a copy of it so s/he can follow. If it is a difficult text, give him or her time to read through it first 
- Stop any overlapping speech or any attempts from lawyers or witnesses to interrupt the interpreter while s/he is interpreting

- Do not assume that the witness will understand legal jargon when interpreted into their language. Interpreters must interpret accurately, and cannot simplify the text or explain legal concepts. If there are no direct equivalents, the interpreter may ask for an explanation which can then be interpreted

- Interpreters are required to interpret vulgar language, including expletives

- Interpreters are required to interpret everything for the defendant or accused, to make them linguistically present. This includes the questions and answers during evidence, any objections, legal arguments and other witness testimonies. The consecutive mode will be used when interpreting questions and answers. The whispering simultaneous mode (AKA chuchotage) will be used for all other instances (if the interpreter is trained in this mode of interpreting)

- If anyone questions the interpreter's rendition, do not take their criticism at face value. Bilinguals who are not trained interpreters often overestimate their competence. Compare qualifications and give the interpreter the opportunity to respond to the criticism

For more information on interpreting issues, refer to: Hale, S. (2011). Interpreter policies, practices and protocols in Australian courts and tribunals. A national survey. Melbourne: AIJA. http://www.aija.org.au/online/Pub\%20 no89.pdf

\section{BIONOTE / NOTA BIOGRÁFICA}

Sandra Beatriz Hale is Professor of Interpreting and Translation at the University of New South Wales, where she teaches interpreting in the Master of Interpreting and Translation Studies. She has over twenty years' experience as an interpreter and translator educator and has designed curricula at undergraduate and post graduate levels. She has lectured in the areas of forensic linguistics, legal, community and conference interpreting, and research methods. She is a NAATI Spanish-English interpreter and translator and has many years of experience interpreting in the community and in legal and international conference settings. Her qualifications include a Bachelor of Arts in Interpreting and Translation, a Diploma of Education (Spanish and Italian), a Master of Applied Linguistics and Doctorate of Philosophy in court 
interpreting. She has recently been awarded a Doctorate Honoris Causa from the University of Antwerp for her contributions to research in Interpreting. She has researched many aspects of interpreting, including issues relating to accuracy, rapport, training and working conditions. She is the sole author of the books The Discourse of Court Interpreting, published by John Benjamins in 2004, and Community Interpreting, published by Palgrave Macmillan in 2007, translated into Spanish in 2010 and into Japanese in 2014, and co-author of Research Methods in Interpreting (2013) with Jemina Napier. She has also written numerous journal articles and book chapters. She is regularly invited to deliver plenary addresses and workshops on interpreting to lawyers, judicial officers and tribunal members as well as to interpreters and academics locally and internationally. She is the co-founder and editor of the international refereed research journal Translation \& Interpreting. The international journal on translation and interpreting research.

Sandra Beatriz Hale es catedrática de Interpretación y Traducción en la Universidad de Nueva Gales del Sur, donde imparte clases de interpretación en el Máster de Estudios de Traducción e Interpretación. Cuenta con más de veinte años de experiencia como profesora en las áreas de lingüística forense, interpretación judicial, en los servicios públicos y de conferencias y en métodos de investigación. Ha diseñado cursos de interpretación y traducción de grado y postgrado para diferentes universidades, al igual que cursillos y talleres para jueces, magistrados, abogados y médicos sobre cómo trabajar con intérpretes. Es intérprete y traductora acreditada por NAATI, con más de veinte años de experiencia. Sus títulos incluyen una Licenciatura en Interpretación y Traducción, un diploma de Educación (español e italiano), una Maestría en Lingüística Aplicada y un Doctorado en Interpretación Judicial. Recientemente ha sido galardonada con un Doctorado Honoris Causa de la Universidad de Amberes por su contribución a la investigación en el campo de la Interpretación. Sus proyectos de investigación han explorado diferentes aspectos de la interpretación, entre los que se encuentran la fidelidad, el rapport, la formación y las condiciones de trabajo. Es autora de los libros The discourse of court interpreting, editado por John Benjamins en 2004, y Community Interpreting, editado por Palgrave Macmillan en 2007 y traducido al español en 2010 y al japonés en 2014. Es co-autora de Research Methods in Interpreting (2013) con Jemina Napier. También ha publicado numerosos artículos y capítulos de libros. Es invitada frecuentemente a dictar conferencias plenarias y talleres sobre interpretación a juristas, así como a intérpretes y académicos en diferentes países. Es la cofundadora y editora de la revista Translation $\&$ Interpreting. The international journal on translation and interpreting research. 